\title{
odd-paired: a zinc finger pair-rule protein required for the timely activation of engrailed and wingless in Drosophila embryos
}

\author{
Mark J. Benedyk, ${ }^{1}$ Janet R. Mullen, ${ }^{1}$ and Stephen DiNardo ${ }^{2}$ \\ The Rockefeller University, New York, New York 10021-6399 USA
}

\begin{abstract}
The pair-rule gene, odd-paired (opa), is essential for parasegmental subdivision of the Drosophila embryo. In addition to its previously defined role in the activation of wingless $(\mathrm{wg})$ in odd parasegments, we find that opa is required for the timely activation of $\mathrm{wg}$ in the remaining parasegments and for the timely activation of engrailed (en) in all parasegments. opa encodes a zinc finger protein with fingers homologous to those of the Drosophila segment polarity gene $\mathrm{ci}^{D}$, the human glioblastoma gene GLI and the Caenorhabditis elegans sex determination gene tra-1. Previous work showed that opa activity was essential for the establishment of alternate parasegments, suggesting opa expression or activity would be spatially restricted like other pair-rule genes. Instead, opa mRNA and protein are found throughout all segment primordia. Thus, opa does not act in a spatially restricted manner to establish the position of en and wg expression. Rather, opa must cooperate with other spatially restricted proteins to achieve proper subdivision of the Drosophila embryo.
\end{abstract}

[Key Words: Drosophila; pair-rule genes; zinc finger protein; segmentation]

Received September 3, 1993; revised version accepted November 22, 1993.

A strategy common to many organisms during embryonic development is the subdivision of the body axis into small domains. Examples of such patterning units are the neuromeres that form in the diencephalon and hindbrain in the developing vertebrate nervous system (Lumsden and Keynes 1989; Figdor and Stern 1993) and the segmental divisions of the insect body (Garcia-Bellido et al. 1973, 1976; Morata and Lawrence 1975; Lewis 1978; Carroll et al. 1988b).

In fly embryos, subdivision along the anteroposterior axis begins with maternally deposited gene products and proceeds via a regulatory hierarchy of gene expression up to the time of cellular blastoderm formation (NüssleinVolhard and Wieschaus 1980; for reviews, see NüssleinVolhard et al. 1985; Ingham 1988). Genes within this hierarchy are expressed in increasingly narrow domains, reflecting the progressive subdivision of the body plan. Most of these genes encode known or presumed transcriptional regulators. Maternal gene products regulate the gap genes, which are expressed in broad domains. The gap proteins contribute to the control of three pairrule genes, hairy ( $h$ ), even-skipped (eve), and runt (run), each of which is expressed in a striped pattern (Ingham et al. 1985; MacDonald et al. 1986; Frasch et al. 1987; Car-

\footnotetext{
${ }^{1}$ These authors contributed equally to the work. ${ }^{2}$ Correspondening author.
}

roll et al. 1988; Gergen and Butler 1988; Goto et al. 1989; Stanojevic et al. 1989; Pankratz et al. 1990). These pairrule proteins, probably with assistance from the gap proteins, activate the other pair-rule genes, fushi tarazu $(f t z)$, paired (prd), odd-skipped (odd), and sloppy-paired (slp) (Carroll and Scott 1986; Howard and Ingham 1986; Frasch and Levine 1987; Baumgartner and Noll 1990). Each of these genes is expressed in dynamic, striped patterns with each stripe encompassing two to four cells (Hafen et al. 1984; Kilchherr et al. 1986; Coulter et al. 1990; Grossniklaus et al. 1992). The last remaining pairrule gene, odd-paired (opa), has been less well-characterized and is the subject of our analysis.

The body plan is further subdivided into small, repeating units, the parasegments (Martinez-Arias and Lawrence 1985), as the segment polarity genes wingless (wg) (Baker 1987) and engrailed (en) (Kornberg et al. 1985) are each activated in 14 single-cell-wide stripes. $w g$ is expressed in the row of cells that defines the posterior edge of each parasegment (Ingham 1991; Dougan and DiNardo 1992), whereas en is expressed in the row of cells that defines the anterior edge of each parasegment (Lawrence et al. 1987; Carroll et al. 1988b). One function of $e n$ and $w g$ is to maintain the parasegmental subdivisions of the body axis. The expression of both of these genes must be controlled with single-cell precision for this to occur (Babu 1977; Kornberg 1981; Nüsslein-Vol- 
hard et al. 1985; Poole and Kornberg 1988; Noordermeer et al. 1992).

Several models suggest that combinatorial interactions among pair-rule proteins restrict the activation of en and wg to single cell-wide stripes (Howard and Ingham 1986; DiNardo and O'Farrell 1987; Ingham et al. 1988; Morrissey et al. 1991; Manoukian and Krause 1992, 1993). For instance, both $f t z$ and opa activity are required for normal en expression in the even parasegments (Howard and Ingham 1986; DiNardo and O'Farrell 1987; Ingham et al. 1988). The $\mathrm{ftz}$ protein is expressed in stripes several cells wide (Carroll and Scott 1985), but en is activated only in the anterior-most of these cells (Lawrence et al. 1987; Carroll et al. 1988a). It was hypothesized that opa would be expressed or active in restricted domains, such that $f t z$ - and opa-expressing cells would overlap in a single-cell-wide stripe in each even parasegment (DiNardo and O'Farrell 1987; Ingham 1988). en would then be activated only in cells expressing both proteins. Recent data have suggested that the repressor odd also limits the expression of en (Manoukian and Krause 1993). The restricted expression of $w g$ was also thought to involve the position-specific expression or activity of the opa gene (Ingham et al. 1988). Here, we report that opa activity is essential for the appropriate level and timing of $e n$ and $w g$ expression in all parasegments, but opa activity does not determine the restricted spatial domains of these genes.

\section{Results}

\section{Body pattern defects}

The segmental pattern of wild-type embryos is easily visible at the end of embryogenesis in the cuticle secreted by epidermal cells. There are three thoracic and eight abdominal segments (Fig. 1A). The anterior of each segment has several rows of cuticular projections, or denticles, comprising a denticle belt. The remainder of each segment consists of smooth cuticle. In opa mutants, only half the number of denticle belts are present as a result of the deletion of alternate segments (Jürgens et al. 1984). The same defects are found in embryos harboring molecularly null opa mutations, $D f(3 R)$ 63/ $D f(3 R) 107$ (Fig. 1B; see below). These segmentation defects result from the failure to establish or maintain the parasegments early in embryogenesis.

opa activity is required for optimal levels of en and $\mathrm{wg}$ in all parasegments

At cellular blastoderm in wild type, $w g$ is expressed in 14 single-cell-wide stripes defining the posterior borders of parasegments 0-13 (Baker 1987; Fig. 1C). In opa null embryos, wg expression never initiates in the odd parasegments, as reported previously for ethylmethane sulfonate (EMS)-induced opa alleles (Ingham et al. 1988). In the even parasegments, $w g$ expression is severely delayed except in parasegments 0 and 2 (Fig. 1D). As development proceeds, $w g$ expression initiates in the even parasegments, 4-12, and approaches normal levels, although it remains spotty (e.g., see Fig. 4B, below). We conclude that opa function is essential for the initiation of $w g$ in the odd parasegments and is important for normal wg expression in the even parasegments. Similarly, opa is required for normal en expression in all parasegments. In wild type, en is expressed in 14 single-cellwide stripes by the onset of gastrulation (Fig. 1E; Kornberg et al. 1985). In opa null mutants at gastrulation, little en expression is visible (Fig. 1F). en expression is severely delayed, but eventually appears in both the odd and even parasegments, indicating that opa is required in all parasegments for the timely activation of en. The defects in both $w g$ and en expression demonstrate that opa is required in the cells that flank each parasegment border, and not only in the cells flanking alternate parasegments borders, as was thought previously (DiNardo and O'Farrell 1987; Ingham et al. 1988). In the earlier analysis of EMS-induced opa alleles, some en expression was detected in the even parasegments. Although this was assumed to be attributable to residual opa activity, we have found that in opa null embryos, en is expressed in the correct position in these parasegments (Fig. $1 \mathrm{H}, \mathrm{P}$; see below). This result indicates that although opa is required for the proper timing of en activation, it is not required for either activation or proper positioning of $e n$ expression in the even parasegments.

\section{The position of en expression in the even} parasegments is determined by $\mathrm{ftz}$ and odd

It has been suggested that, in the even parasegments, the position of en expression is defined by the presence of the activator $f t z$ and the absence of odd, a presumed repressor of en (Manoukian and Krause 1993). We investigated whether opa mutants exhibited changes in the expression of $\mathrm{Ftz}$ protein and odd mRNA that could account for the defects in en expression. During cellularization in wild type, $\mathrm{Ftz}$ is expressed in seven stripes approximately three cells wide, corresponding to the anterior-most cells of the even parasegments (Carroll and Scott 1985). At the same time, odd transcript appears in seven broad primary stripes that overlap completely with the cells expressing Ftz (Coulter et al. 1990; Manoukian and Krause 1992). By gastrulation, odd expression (blue color in Fig. $1 \mathrm{~K}$ ) is repressed in the anteriormost $\mathrm{Ftz}^{+}$cells (brown color in Fig. 1I), leaving each Ftz stripe extending one or two cell diameters anterior to each primary odd stripe. It is these anterior-most $\mathrm{Ftz}^{+}$ cells that activate en (Fig. 1E; Lawrence et al. 1987; Carroll et al. 1988a). After cellularization, odd expression is initiated in secondary stripes within the odd parasegments (Fig. 1I, K; Coulter et al. 1990).

In opa mutants, the secondary odd stripes fail to appear (Fig. 1J), indicating that opa is required for the activation of odd expression in the odd parasegments. In addition, the expression of odd in its primary stripes remains coincident with the $\mathrm{Ftz}{ }^{+}$cells at a stage where, in wild type, odd expression has been lost from these anterior-most $\mathrm{Ftz}^{+}$cells (Fig. $1 \mathrm{~K}, \mathrm{~L}$ ). This suggests that the 
WI
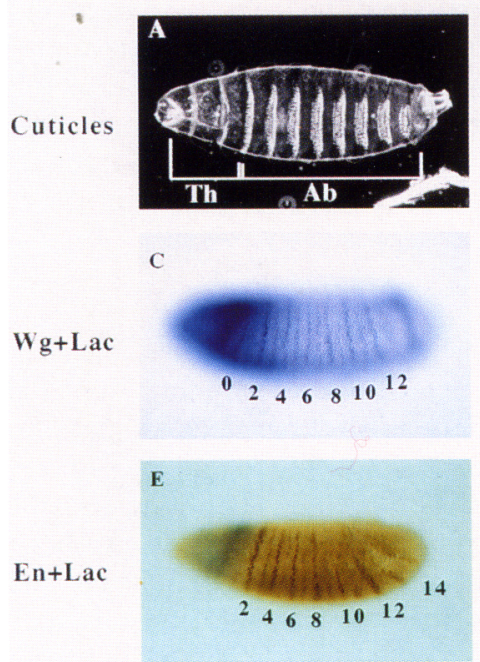

G

En+Lac

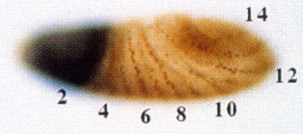

ора

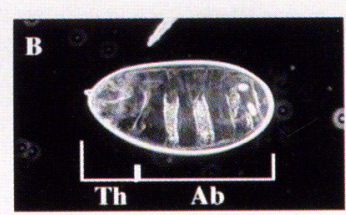

D
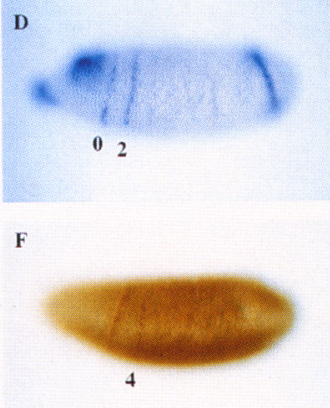

H

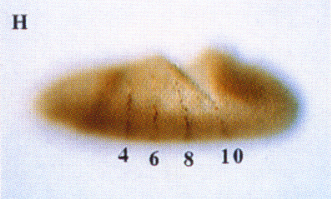

WT
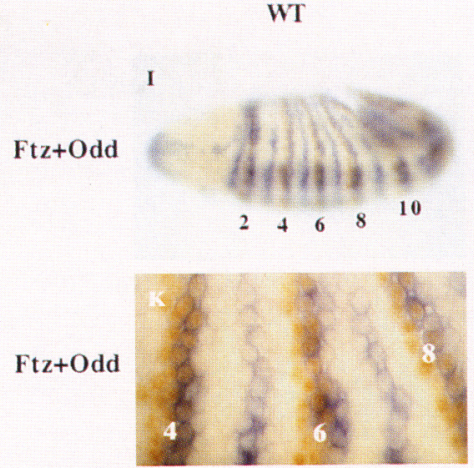

M

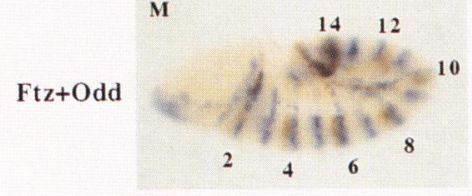

o

En+Lac

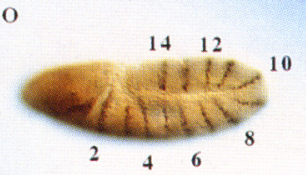

opa
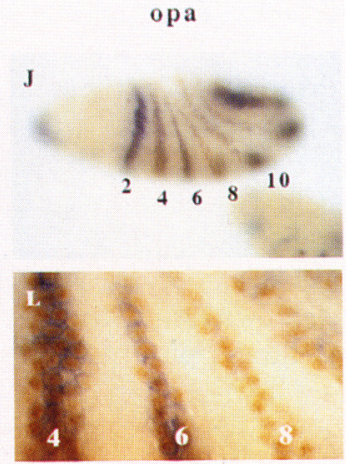

$\mathbf{N}$

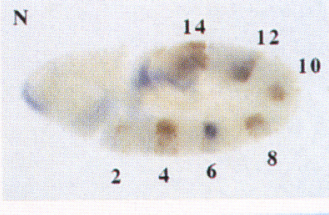

$\mathbf{P}$

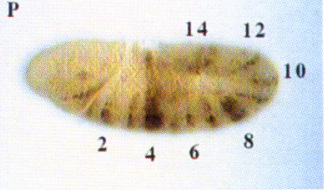

Figure 1. The regulation of $w g$, en, odd, and ftz expression by opa. (A) Wild-type cuticle; anterior to the left. $(B)$ opa null cuticle, $\mathrm{Df}(3 \mathrm{R}) 63 / \mathrm{Df}(3 \mathrm{R})$ 107, only half of the segments develop. Most of each odd abdominal denticle belt is deleted. The anterior half of each even segment is fused to the posterior remnant of each odd denticle belt (Ingham and Martinez-Arias 1986). Embryos in C-P are anterior left, ventral down. All opa mutants are null. $(C, D)$ Cellular blastoderm labeled in situ for wg and lacZ RNA. (C Wild type; $w g$ is expressed in parasegments $0-13$, and $l a c Z$ is expressed anteriorly from the $h b-l a c Z$ transgene on the balancer chromosome. (D) $o p a ; w g$ is expressed only in parasegments 0 and 2. The anterior patch of wg expression, the head "blob" (obscured by lacZ in $C$ ), and the posterior ring are established normally in opa mutants. $(E-H)$ Labeled in situ for $l a c Z$ and En. $(E)$ Wild-type stage 7; En is expressed in 14 stripes. $(F)$ opa stage 7; En is expressed only in parasegment $4 .(G)$ Wild-type stage 8; En stripes are well established. $(H)$ opa stage 8; En is just appearing, first in parasegments 4 and 8 , then in parasegments 6 and 10. The previous analysis of en expression in opa mutants suggesting that these were the odd en stripes is incorrect (Ingham and Martinez-Arias 1986; DiNardo and O'Farrell 1987). opa embryos doubly labeled for $w g$ and en expression confirm that these En stripes correspond to the even parasegments (data not shown). $(I-N)$ Embryos doubly labeled for odd RNA (blue) and Ftz protein (brown). (I) Wild-type stage 8; odd stripes in the even parasegments have narrowed to single-cell width, whereas Ftz stripes are roughly two cells wide. The secondary odd stripes have appeared in the odd parasegments. $(/)$ opa stage 8 ; secondary odd stripes never appear, clearly marking the mutant embryos. odd expression persists at relatively high levels in parasegment 2, where en induction is lowest (see $H)$. $(K)$ Magnified view of parasegments 4-10 of wild type in $I$. Each Ftz stripe extends one to two cell widths anterior to each primary odd stripe. $(L)$ Magnified view of parasegments 4-10 of opa null in $J$. Ftz remains strong and broad in parasegment 4, rather than narrowing (cf. with $K$ ). odd expression is beginning to clear from anterior-most Ftz cells of parasegments 4 and 8, where en expression appears first in opa mutants (see $F$ ). odd expression remains coincident with Ftz cells in parasegment 6, where en expression is more severely delayed (see $H)$. (M) Wild-type stage 9; Ftz stripes have retracted to about one cell wide, just anterior to the primary odd stripes. $(N)$ opa stage 9; Ftz fades early in parasegment 2. High-level odd persisting in parasegments 2 (see /), may cause the early loss of Ftz, because odd represses ftz expression in wild type (J. Mullen and S. DiNardo, in prep.). Early loss of Ftz in parasegment 2 could be the cause of very weak En expression in this parasegment (see $H$ ). Ftz is quite broad in parasegments 4 and 8, and odd has faded from parasegments 4 and 8, correlating with the broadening of En in these parasegments at this stage (see $P$ ). (O) Wild-type stage 9; En is expressed in 14 evenly spaced stripes. $(P)$ opa stage 9; En is broad in parasegments 4 and 8 . En expression in the odd parasegments is established, although all stripes are stronger ventrally than dorsally. In older opa embryos, en expression in the even parasegments decays, as reported previously (data not shown) (Ingham and MartinezArias 1986; DiNardo and O'Farrell 1987).

delay in activation of en in even parasegments is attributable to persistent odd expression. A continued correlation between coincident odd and Ftz expression and the delay in en activation in opa mutants supports this notion.

During early germ-band extension in opa mutants, odd expression is lost from the anterior-most $\mathrm{Ftz}^{+}$cells of parasegments 4 and 8 (Fig. 1L). About this time, en expression first appears in parasegments 4 and 8 (Fig. 1H). The close timing of these events suggests that Ftz can activate $e n$ in the anterior-most cells of its domain only after odd activity is removed. Around mid-germband extension, the Ftz stripes become particularly broad in parasegments 4 and 8 , and odd expression in these parasegments is no longer detectable (Fig. 1N). Shortly thereafter, the en stripes in parasegments 4 and 8 
broaden to about twice wild-type width (Fig. 1P) correlating with the presence of Ftz and the absence of odd expression in these cells. This supports the model of Manoukian and Krause in which the position of en expression is determined by the offset of the expression domains of the odd gene product and Ftz (Manoukian and Krause 1993).

The effects on $w g$, en, ftz and odd expression demonstrate that opa activity not only is required at cellular blastoderm in the cells that flank each parasegment border but also in most cells within each parasegment. Thus, opa is required throughout the segmented region of the embryo and not in discrete domains, distinguishing opa from all the other pair-rule genes. To understand how opa may execute its roles, we cloned and sequenced the opa gene and analyzed the expression of both transcript and protein.

\section{Localization and cloning of the opa gene}

By generating deficiencies [Fig. 2; see Materials and methods (Letsou et al. 1991)] we refined the opa map position (Jürgens et al. 1984) to the interval $82 \mathrm{D}_{(3-8)}$; $82 \mathrm{E}_{(3-4)}$ and used a phage clone that mapped to the $82 \mathrm{D}$ region to begin a chromosome walk. To identify putative candidate phage from within the walk, each clone was used as an in situ probe on blastoderm embryos. Only clones 6, 7, and 8 (Fig. 2) exhibited strong hybridization, detecting message expressed from $\sim 20 \%$ to $80 \%$ egg length (not shown, but identical to Fig. 7B, below). These three phage clones also covered the DNA missing from two small deletions that failed to complement opa, $D f(3 R) 107$ and $D f(3 R) 63$ (data not shown and Fig. 2). Subfragments from each of these phage clones were iso-

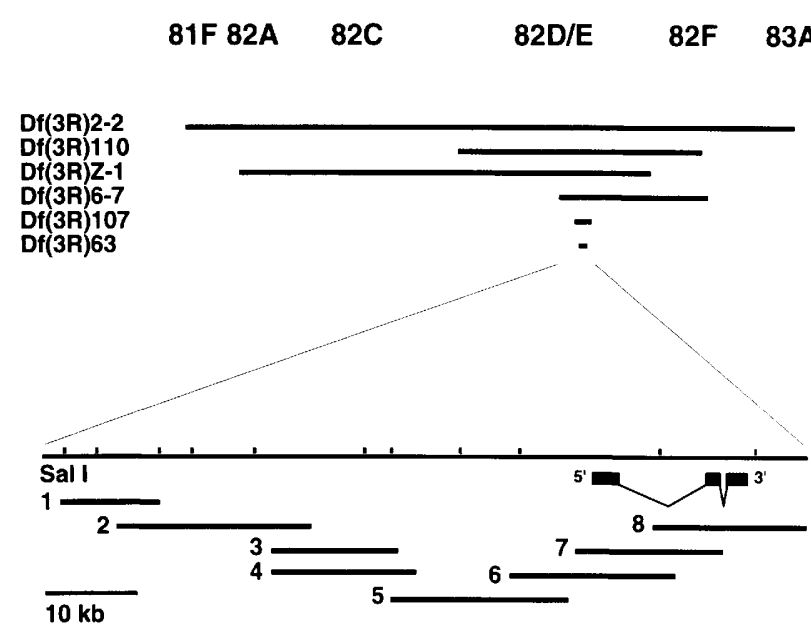

Figure 2. Deficiency maps and cDNA structure of opa. Deficiency chromosomes in the cytological interval 81F-83A. Solid lines indicate missing DNA. The Sall sites in the region cloned from $82 \mathrm{D} / 82 \mathrm{E}$, are shown below. The chromosome walk, which was initiated to the left of $D f(3 R)$ 6-7, is represented by phage clones $1-8$. The opa transcript spans phage clones $6-8$. The exons depicted are located in the restriction fragments shown on the Sall map, but are not drawn to scale. lated, individually labeled, and hybridized to embryos. Two of the fragments exhibited the same pattern on embryos as the parent phage. These two fragments identified a $\sim 3-\mathrm{kb}$ message on Northern blots of 2.5- to 5.0-hr embryonic mRNA. Four cDNA clones obtained using these fragments each exhibited hybridization results identical to those obtained with the genomic clones (see Figs. 6 and 7, below).

\section{Rescue of the opa mutant phenotype}

Sequencing and primer extension experiments identified one of the clones, opaC, as a full-length cDNA /data not shown). Two complementation assays were used to test whether it was the opa gene. First, capped transcripts synthesized in vitro from opaC injected into embryos during the syncytial blastoderm rescued the cuticle phenotype of 8 of 16 opa embryos (Materials and methods; data not shown). We then constructed transgenic flies in which the opaC cDNA was placed under the control of the hsp70 promoter (HSopaC). opa ${ }^{5 H}$ homozygous embryos have only four complete abdominal segments (Fig. $3 \mathrm{~A})$, although occasionally the remnants of a fifth denticle belt are found. When transgenic embryos were exposed to a $20-\mathrm{min}$ heat shock during cellularization, 16 of $27(59 \%)$ and 22 of $48(46 \%)$ opa mutants showed rescue as judged by the presence of at least five full denticle belts (Fig. 3B,C). In some cases, rescue approximated the wild-type body pattern (Fig. 3C). No rescue was found in heat-shocked embryos that did not harbor the transgene.

We then asked whether the rescue of body pattern correlated with the restoration of $w g$ and en expression. In $o p a^{7 N}$ mutants, the wg stripes in the odd parasegments are missing (cf. Fig. 4, A and B). In opa mutants carrying the HSopaC transgene, wg expression was restored in odd parasegments $3-11$ (Fig. 4 C). wg rescue was found in 25 of $40(62 \%)$ of the opa mutant transgenic embryos assayed. No rescue was found in heat-shocked embryos that did not harbor the transgene. en expression was also rescued in opa mutants carrying the HSopaC transgene. About $1 \mathrm{hr}$ after cellularization in opa mutants, en expression is usually absent from parasegment 2, is spotty and broad in parasegments 4 and 8 , and fails to extend dorsally in all stripes (cf. Fig. 4, D and E). In contrast, 29 of $54(54 \%)$ of the opa transgenic embryos exhibited en expression in parasegment 2, narrower en stripes in parasegments 4 and 8 , and more extensive dorsal expression in all stripes (Fig. 4F). Although en expression was partially restored, some defects remained in the positioning of the stripes such that odd parasegments appeared narrower than the even parasegments (Fig. 4F). The significant rescue of both target gene expression and final body pattern demonstrates that this is the opa gene. There are several possible reasons why rescue did not approach $100 \%$ efficiency. First, heat shock during cellularization may lead to translation of opa after its normal peak requirement. Second, there may be a postblastoderm requirement for opa that will not be fulfilled by a single heat pulse during cellularization. Third, we recently 


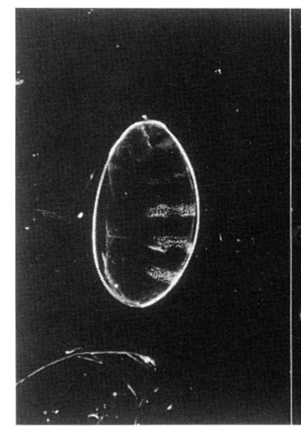

A. + ; opa $5 \mathrm{H}$

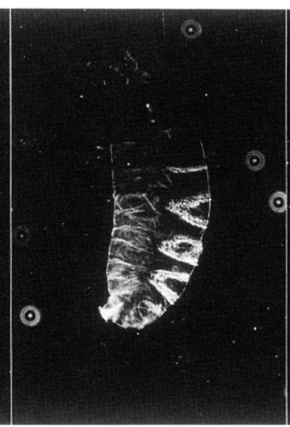

B. hs-opa; opa $5 \mathrm{H}$

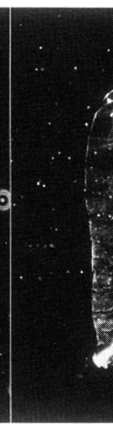

C. hs-opa; opa $5 \mathrm{H}$

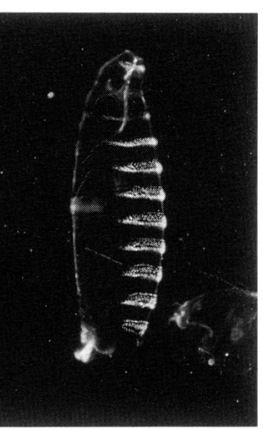

D. wildtype
Figure 3. Rescue of opa body pattern by the HSopaC transgene. Cuticles oriented anterior up, ventral to right, dark-field images. $(A) o p a^{5 H} / o p a^{5 H}$. Embryos have four completely fused abdominal denticle belts resulting from loss of alternate body segments; only three of these compound segments are visible in this photo. Compare with wild type in $D$. (B) HSopa; opa $a^{5 H} /$ $o p a^{5 H}$. Partially rescued embryo with splitting of denticle belt fusions. $(C)$ HSopa; $o p a^{5 H} / o p a^{5 H}$. Fully rescued embryo. All eight abdominal denticle belts are present. (D) Wild type. Eight abdominal denticle belts are present. learned that the opaC cDNA contains a frameshift resulting in a truncated protein, which nevertheless rescues, but may have affected, rescue frequency (see Materials and methods).

\section{Structure of the opa gene and deduced protein sequence}

Gene structure was determined using a combination of PCR and sequencing comparisons between genomic and cDNA clones (Materials and methods). The transcription unit spans a total of $14.5 \mathrm{~kb}$ of genomic sequence with introns of $\sim 12$ and $0.4 \mathrm{~kb}$ separating the three exons (Fig. 2). The opa transcript is $2959 \mathrm{bp}$ in length, which corresponds well with the transcript size determined by
Northern blotting (see below). Sequence analysis at the $5^{\prime}$ end of the opaC cDNA and of the corresponding genomic region revealed a consensus cap site (GCAGTCCTGC) beginning 1 nucleotide upstream of opa. Primer extension experiments using a primer from +148 to +119 yielded two main products of 147 and 148 nucleotides in length and a minor product of 149 nucleotides (data not shown), indicating that opaC represents a full-length transcript. Three adjacent in-frame translation initiation codons are found at positions 294, 297, and 300 (Fig. 5A), and the sequence surrounding the first ATG matches the Drosophila translation start consensus (Cavener 1987). Conceptual translation of the 1827nucleotide open reading frame yields a protein of 609 amino acids (Fig. 5A). The predicted protein contains five
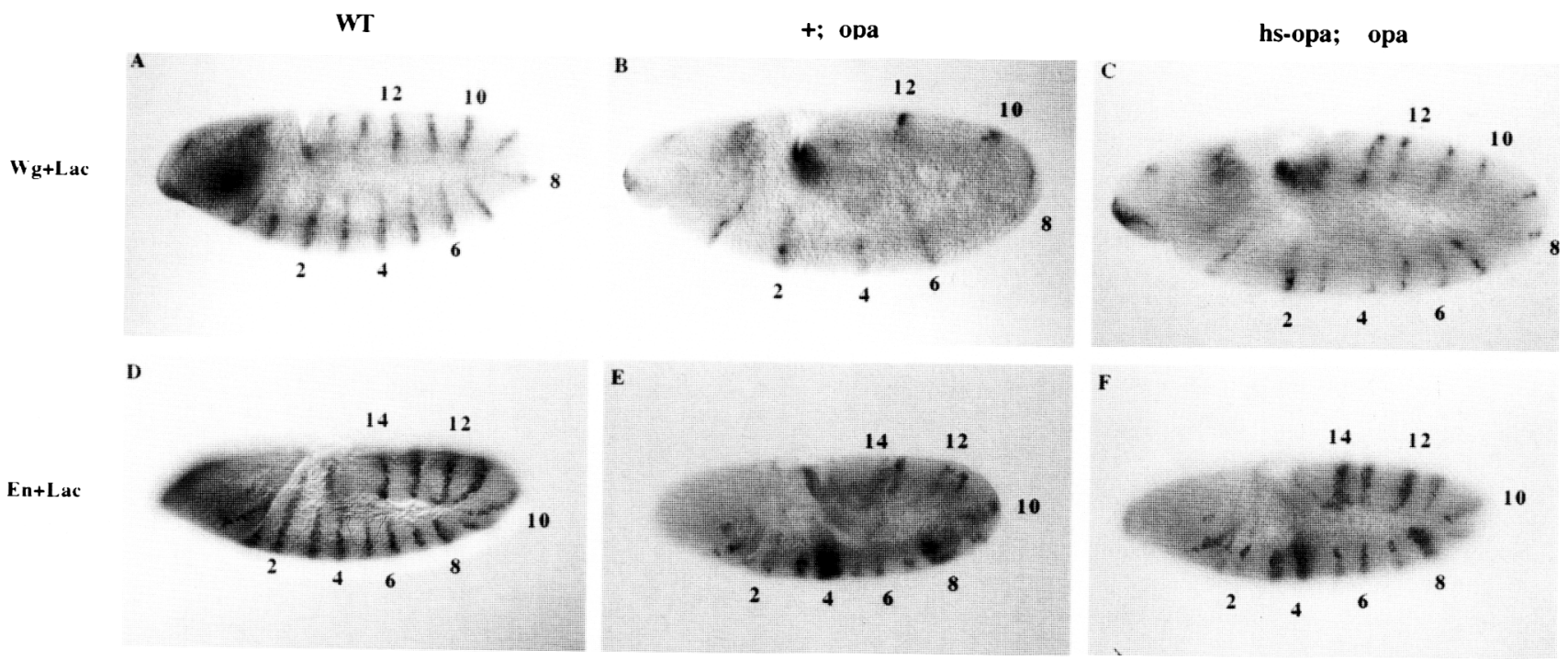

Figure 4. Rescue of $e n$ and $w g$ target gene expression by the HSopaC transgene. $(A-C)$ Stage 9 embryos labeled in situ for wg and lac $Z$ RNA. (A) Wild type. wg is expressed in parasegments $0-13$, and $l a c Z$ is expressed in the anterior from the $h b-l a c Z$ transgene on the balancer chromosome. $(B) o p a^{7 N} / o p a^{7 N}$. wg is not expressed in the odd parasegment, and is expressed weakly in the even parasegments. (C) HSopa; opa $a^{7 N} / \mathrm{opa}^{7 N} 1 \mathrm{hr}$ after heat shock. wg expression is restored to odd parasegments 3-13. (D-F) Stage 9 embryos labeled for En protein. $(D)$ Wild type. En is expressed in parasegments 1-14 and $\beta$-galactosidase in the head because of the presence of the TM3 $p t h b-l a c Z$ balancer chromosome. $(E) o p a^{7 N} / o p a^{7 N}$, En is expressed in parasegments 4 and 8 in broad stripes, and all En stripes are weak dorsally. $(F)$ HSopa; opa ${ }^{7 N} / o p a^{7 N}, 1$ hr after heat shock. En expression is narrower in parasegments 4 and 8 , and En is more robust and extends more dorsally in all parasegments. 


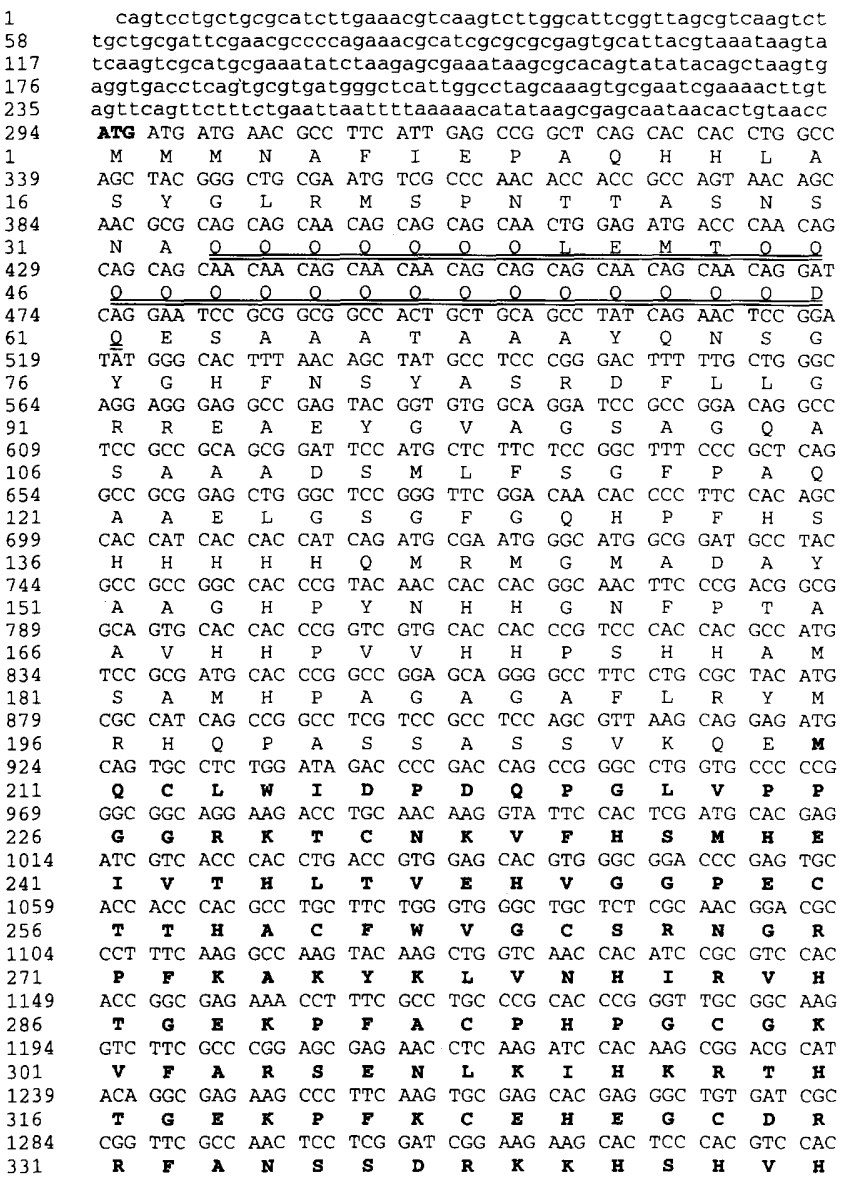

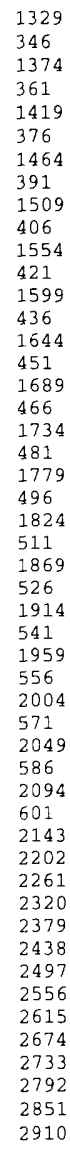

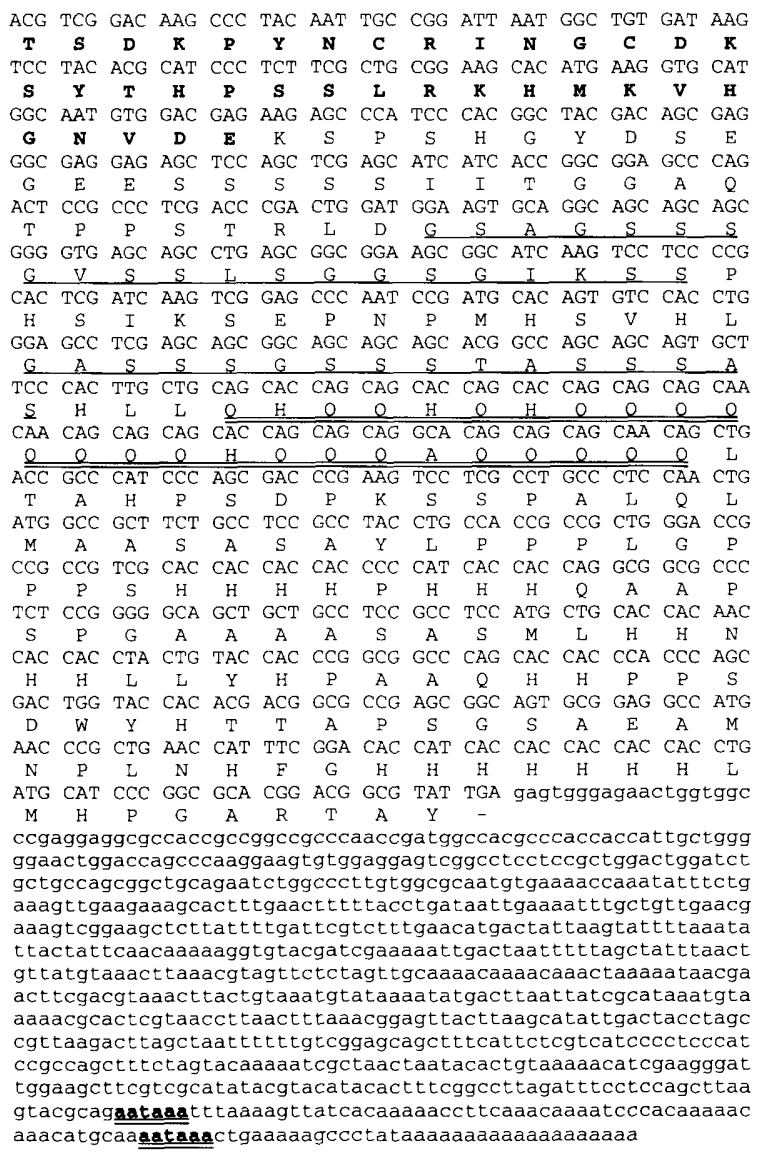

ACG TCG GAC AAG CCC TAC AAT TGC CGG ATT AAT GGC TGT GAT AAG $\begin{array}{ccccccccccccccc}\mathbf{T} & \mathbf{S} & \mathbf{D} & \mathbf{K} & \mathbf{P} & \mathbf{Y} & \mathbf{N} & \mathbf{C} & \mathbf{R} & \mathbf{I} & \mathbf{N} & \mathbf{G} & \mathbf{C} & \mathbf{D} & \mathbf{K} \\ \text { TCC } & \text { TAC } & \text { ACG } & \text { CAT } & \text { CCC } & \text { TCT } & \text { TCG } & \text { CTG } & \text { CGG } & \text { AAG } & \text { CAC } & \text { ATG } & \text { AAG } & \text { GTG } & \text { CAT }\end{array}$ $\begin{array}{ccccccccccccccc}\mathbf{S} & \mathbf{Y} & \mathbf{T} & \mathbf{H} & \mathbf{P} & \mathbf{S} & \mathbf{S} & \mathbf{L} & \mathbf{R} & \mathbf{K} & \mathbf{H} & \mathbf{M} & \mathbf{K} & \mathbf{V} & \mathbf{H} \\ \text { GGC } & \text { AAT } & \text { GTG } & \text { GAC } & \text { GAG } & \text { AAG } & \text { AGC } & \text { CCA } & \text { TCC } & \text { CAC } & \text { GGC } & \text { TAC } & \text { GAC } & \text { AGC } & \text { GAG }\end{array}$ $\begin{array}{lllllllllllllll}\mathbf{G} & \mathbf{N} & \mathbf{V} & \mathbf{D} & \mathbf{E} & \mathrm{K} & \mathrm{S} & \mathrm{P} & \mathrm{S} & \mathrm{H} & \mathrm{G} & \mathrm{Y} & \mathrm{D} & \mathrm{S} & \mathrm{E}\end{array}$ $\begin{array}{lllllllllllllll}G & E & E & S & S & S & S & S & I & I & T & G & G & A & Q\end{array}$ AC $\begin{array}{ccccccccccccccc}\text { T } & \text { P } & \text { P } & \text { S } & \text { T } & \text { R } & \text { L } & \text { D } & \text { G } & \text { S } & \text { A } & \text { G } & \text { S } & \text { S } & S \\ \text { GGG } & \text { GTG } & \text { AGC } & \text { AGC } & \text { CTG } & \text { AGC } & \text { GGC } & \text { GGA } & \text { AGC } & \text { GGC } & \text { ATC } & \text { AAG } & \text { TCC } & \text { TCC } & \text { CCG }\end{array}$

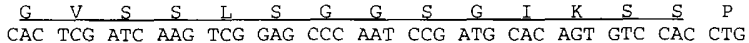

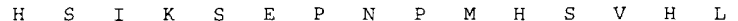
GGA GCC TCG AGC AGC GGC AGC AGC AGC ACG GCC AGC AGC AGT GCT $\begin{array}{ccccccccccccccc}G & A & S & S & S & G & S & S & S & T & A & S & S & S & A \\ \text { TCC CAC } & \text { TTG } & \text { CTG } & \text { CAG } & \text { CAC } & \text { CAG } & \text { CAG } & \text { CAC } & \text { CAG } & \text { CAC } & \text { CAG } & \text { CAG } & \text { CAG CAA }\end{array}$

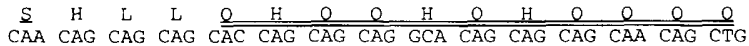
$\begin{array}{cccccccccccccc}0 & 0 & 0 & 0 & H & 0 & 0 & 0 & A & 0 & 0 & 0 & 0 & 0\end{array}$ $\begin{array}{ccccccccccccccc}\text { T } & \text { A } & \text { H } & \text { P } & \text { S } & \text { D } & \text { P } & \text { K } & \text { S } & \text { S } & \text { P } & \text { A } & \text { L } & \text { Q } & \text { L } \\ \text { ATG } & \text { GCC } & \text { GCT } & \text { TCT } & \text { GCC } & \text { TCC } & \text { GCC } & \text { TAC } & \text { CTG } & \text { CCA } & \text { CCG } & \text { CCG } & \text { CTG } & \text { GGA } & \text { CCG }\end{array}$

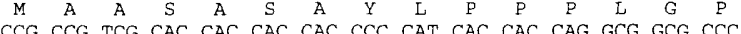

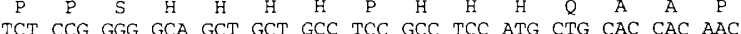
$\begin{array}{lllllllllllllll}S & P & G & A & A & A & A & S & A & S & M & \text { L } & H & H & N\end{array}$ CAC CAC CTA CTT TAC CAC CCC OCO CCC CAC CAC CAC CCA CCC AGC $\begin{array}{lllllllllllllll}H & H & L & L & Y & H & P & A & A & Q & H & H & P & P & S\end{array}$

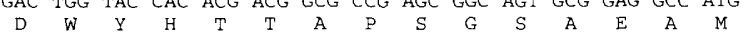
AAC CCG CTG AAC CAT TTC GGA CAC CAT CAC CAC CAC CAC CAC CTG

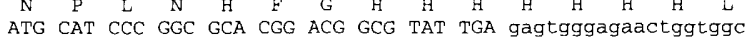

ggaactggact

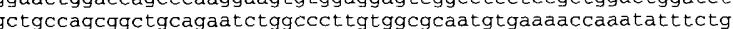
aaagttgaagaaagcact tgaacttttacctgataat tgaaaattgctgttgaacg aaagtcggaagctcttatttgattcgtctttgaacatgactattaagtatttaa ta ttactatcaacaaaaaggtgtacgatcgaaaaattgactaattttagctatttaact act tcgacgtaaact gctgatgata aaaacgcactcgtaaccttaactttaaacggagttacttaagcatattgactacctagc taagact tagctaatttttgtcggagcagctttcattctcgtcatcccctcccat tggaagct tcgtcgcatatacgtacatacact t c cgcct agatt tcctccagcttaa

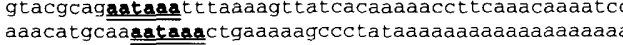

Figure 5. Nucleotide and protein sequence of opa, a GLI- $K r$ class zinc finger protein. (A) Conceptual translation of the opaC cDNA. Noncoding nucleotides are in lowercase. Start and stop codons are in boldface type at nucleotides 294 and 2121, respectively. The first ATG matches the Drosophila consensus (Cavener 1987). Polyadenylation signal sequences are present at 2858 and 2918 nucleotides and are indicated by bold underlined type. The polyserine and polyglutamine repeats are shown in single and double underlined type, respectively. Zinc finger domains are depicted in boldface type. $(B)$ Amino acid sequence alignment of the zinc finger domains of Opa, GLI, $\mathrm{Ci}^{\mathrm{D}}$, and Tra-1. Interfinger linker regions are underlined. Identical residues are indicated by an asterisk (*), conservative substitutions by a caret $\langle\hat{\mid}\rangle$, and residues corresponding to the GLI consensus finger sequence are indicated by boldface type. As the GLI and GLI3 proteins share $88 \%$ identity across their finger domains (Ruppert et al. 1990 |, only GLI is shown in the alignment.

\section{B}

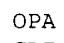

GLI

TRA-1

OPA

GLI

CID TRA-1

OPA

GLI

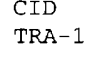

OPA

GLI

TRA-1
MQCLWIDPDQPGLVPPGGRKTCNKVFHSMHEIVTHLTVEHVGGPECTTHA aa \#259 CRW-_........-DGCSOEFDSQEQLVHHINSEHTHG---ERKE aa \#267 CHW-_.......--RRCRIEFITQDELVKHINNDHIQT---NKKA aa \#483 -CRW-....... KSCNSSFQTLKALVDHVQESHVQSTEQEHHA a \#243

-CFWVGCSRNGRPFKAKYKLVNHIRVHTGEKPFACPHPGCGKVFARSEN aa \#307 FVCHWGGCSRELRPFKAQYMLVVHMRRHTGEKPHKCTFEGCRKSYSRLEN aa \#317 FVCRWEDCTRGEKPFKAQYMLVVHMRRHTGEKPHKCTFEGCFKAYSRLEN aa \#533 WRCEWEGCDRNET-FKALYMLIVHVRRHTGEKPNKCEYPGCGKEYSRLEN aa \#292

LKIHKRTHTGEKPFKCEHEGCDRRFANSSDRKKH-SHVHTSDKPYNCRIN aa \#356 LKTHLRSHTGEKPYMCEHEGCSKAFSNASDRAKHONRTHSNEKPYVCKLP aa \#367 LKTHLRSHTGEKPYTCEY PGCSKAFSNASDRAKHQNRTHSNEKPYICKAP aa \#583 LKTHRRTHTGEKPYKCEFADCEKAFSNASDRAKHQNRTHSNLKPYSCQIP aa \#292

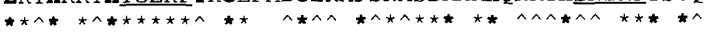

GCDKSYTHPSSLRKHMK-VH aa \#375 GCTKRYTDPSSLRKHVKTVH aa \#387 GCTKRYTDPSSLRKHVKTVH aa \#603 QCTKSYTDPSSLRKHIKAVH aa \#362
$\mathrm{C}_{2} \mathrm{H}_{2}$ zinc finger domains. Between several of the fingers, there are conserved stretches of amino acids [(T/ $\mathrm{S} \mid \mathrm{GEKP}]$, known as $\mathrm{H} / \mathrm{C}$ links, that were first identified in the Drosophila gap gene Krüppel $(K r)$ (Preiss et al. 1985). The predicted Opa protein also contains stretches of polyserine and polyglutamine repeats, motifs com- mon to many transcription factors. The zinc finger region, from amino acid position 210 to 380 was the only domain exhibiting significant homology to other proteins. The most homologous zinc finger domain sequences found were Drosophila $\mathrm{Ci}^{\mathrm{D}}$, human GLI and GLI3, and Caenorhabditis elegans Tra-1 (Fig. 5B; Eaton 
and Kornberg 1990; Orenic et al. 1990; Ruppert et al. 1990; Zarkower and Hodgkin 1992). Fingers 3-5 of Opa fit the GLI consensus sequence $\left[\mathbf{Y} / \mathrm{FXCX}_{3} \mathbf{G C X}_{3}(\mathbf{F} /\right.$ $\left.\mathbf{Y} \mid \mathbf{X}_{5} \mathbf{L X}_{2} \mathbf{H X}_{3-4} \mathbf{H}\right]$, and the $\mathrm{H} / \mathrm{C}$ link consensus $[(\mathrm{T} /$ S)GEKP]. There is $42 \%(70 / 167)$ identity between Opa and all of the other proteins for both consensus and nonconsensus residues within the zinc finger region. All four proteins lack a perfect consensus for the first finger and are missing consensus linker residues between the first and second fingers. Opa has 21 conservative substitutions compared with the GLI, $\mathrm{Ci}^{\mathrm{D}}$, and Tra- 1 zinc finger sequences, indicating that these proteins are more similar to each other than to Opa. We found no significant homology between Opa and these proteins outside of the finger domains.

opa $m R N A$ and protein expression during embryogenesis

Northern blotting experiments with an opaC probe revealed a single mRNA of $3 \mathrm{~kb}$ with peak expression between 2 and $12 \mathrm{hr}$ of embryogenesis (Fig. 6). Expression of this transcript continues throughout the larval instars and during pupation, although at lower levels compared with embryogenesis. Some transcript was found in unfertilized eggs, indicating that there may be a small maternal contribution. We focus here on the zygotic expression and function of the gene.

opa transcript first appears at the beginning of cellularization (stage 5) (Campos-Ortega and Hartenstein 1985 ) in a stripe $\sim 10$ cells wide centered at $80 \%$ egg length (Fig. 7A). Expression then extends posteriorly, and the level of expression increases, generating uniform expression between $20 \%$ and $80 \%$ egg length (Fig. $7 \mathrm{~B}$ ), with the posterior border of this domain more sharply defined than the anterior. The expression pattern does not change during gastrulation (stage 6). Once germ-band extension begins (stage 7), the level of ectodermal expression begins to decrease. Transcript fades more from par-

opa

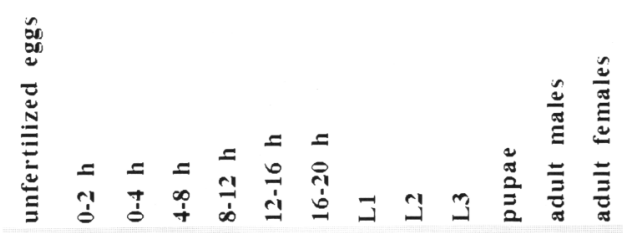

RP49

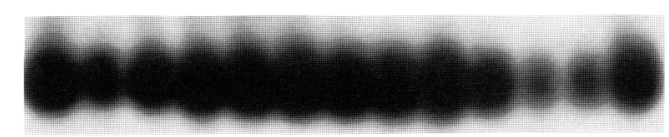

Figure 6. Developmental expression of opa mRNA. Lanes are as indicated. opa expression peaks between 2 and $12 \mathrm{hr}$ after egg laying (top). Expression of a ribosomal protein gene, RP49, is used as a loading control (bottom).
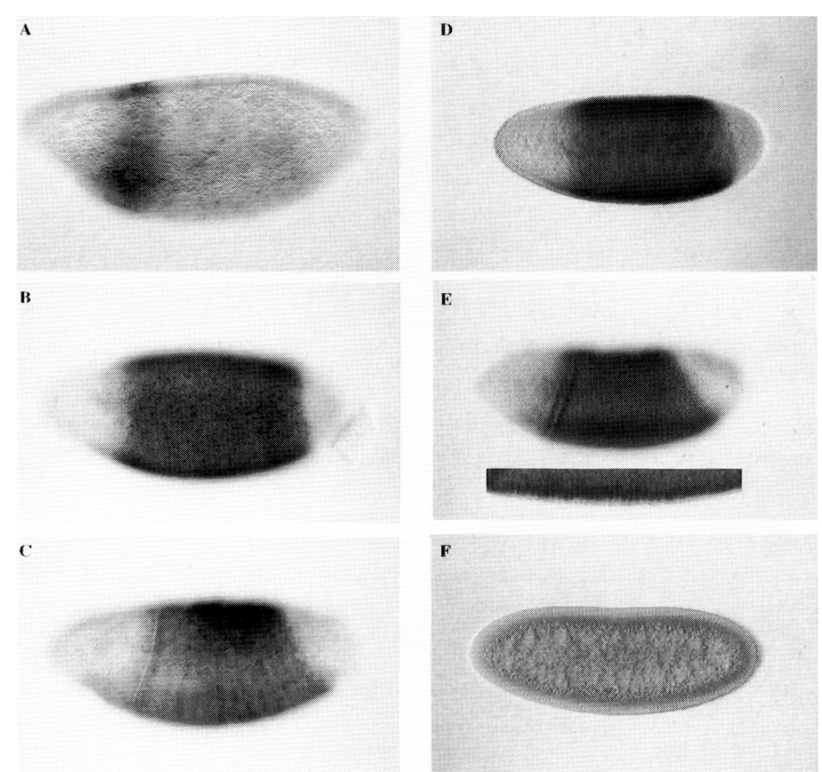

Figure 7. opa mRNA is expressed throughout the segmented region of the body. $(A-C)$ Wild-type embryos probed in situ for opa RNA. (A) Early stage 5; opa RNA appears in a 10-cell-wide patch at $\sim 80 \%$ egg length. $(B)$ Late stage 5; opa is expressed at peak levels in a broad domain from $20-80 \%$ egg length, with a sharp posterior edge and a fuzzier anterior edge. $(C)$ stage 7 ; opa is still expressed throughout all segment primordia but a faint periodicity in expression is appearing. Expression levels decrease dramatically in the ectoderm after this stage. Wild type $(D, E)$ and opa null $\langle F\rangle$ all labeled with rabbit polyclonal antibodies raised against the Opa protein. $(D)$ Late stage 5; Opa expression extends from $20-80 \%$ egg length (cf. with $B$ ). (E) Stage 6/7; Opa remains expressed in a broad domain, with no stripes visible. Magnified view of ventral ectoderm shows that Opa accumulates mostly in the nuclei. (F) opa null Df(3R) 63/Df(3R) 107 expresses no detectable Opa protein.

ticular cells within each parasegment, generating 14 weak stripes over a low background level of expression (Fig. 7C). This is the first stage at which there is some periodicity to opa expression, but it does not approximate the sharp on-off expression patterns observed for other pair-rule genes. Opa protein is present in a block from $20 \%$ to $80 \%$ egg length during cellularization, and protein levels peak late during cellularization and into gastrulation (Fig. 7D,E), paralleling expression of opa mRNA (cf. Fig. 7, B with D, and C with E). Antibody specificity was determined by staining embryos heteroallelic for $D f(3 R) 107$ and $D f(3 R) 63$, both of which delete opa-coding sequences. The opa null embryos were devoid of signal (Fig. $7 F$ ), indicating that the antibody is specific for Opa; or if there are any cross-reacting antigens, they are under the control of the opa gene.

Opa accumulates in the nuclei, although some staining is visible in the basal cytoplasm of ectodermal cells (Fig. 7E, inset). Throughout gastrulation Opa remains expressed in a solid block. During early germ-band extension, Opa expression levels decline compared with the peak at cellular blastoderm, although the protein re- 
mains homogeneously expressed within the segmented region of the ectoderm. As germ-band extension continues, weak stripes evolve over a low level background of Opa expression (data not shown), similar to those of the transcript pattern.

\section{Discussion}

The loss of opa function leads to pair-rule defects in the body pattern. opa, however, is a ubiquitous factor expressed throughout all segment primordia and not spatially restricted as are other pair-rule proteins. Thus, the generation of parasegmental subdivisions requires that opa assists localized factors. We discuss how the molecular nature of the Opa protein may explain this cooperation. In addition, we consider how, in opa mutants, the early global defects in gene expression are partially resolved through subsequent cellular interactions such that only pair-rule defects are generated in the final body pattern.

\section{Opa function may vary in the presence of other transcription factors}

Strikingly, opa exhibits no periodicity in its early expression. In every cell at blastoderm for which a marker gene exists, we find an expression defect in opa mutants, suggesting that Opa is active in most and probably all cells of each segment primordium at blastoderm. Genetically, Opa positively regulates some genes while negatively regulating others. It is likely that Opa executes these genetic roles by directly regulating transcription, because several Drosophila $\mathrm{Kr}$ class finger proteins have been shown to act directly as transcriptional regulators (Sauer and Jäckle 1991; Zuo et al. 1991). Opa has an alanine-rich region (residues 94-122, 34\% alanine rich), a motif shown to be required for transcriptional repression in cultured cells (Licht et al. 1990). Opa also has two polyglutamine repeats, which have been shown to activate transcription (Courey and Tjian 1988; Courey et al. 1989). These motifs suggest that Opa may either activate or repress transcription upon interacting with a given target gene. Other ubiquitously expressed proteins have been shown to both activate and repress transcription in different contexts. The GLI- $K r$ class protein YY-1 (NFE1/UCRBP/CF-1) either activates or represses transcription at the adeno-associated virus $\mathrm{p} 5$ promoter, depending on the presence or absence, respectively, of the E1A protein (Shi 1991). In addition, YY-1 present throughout B-cell development (Kakkis 1989) can either activate transcription via a c-myc YY-1-binding site or repress transcription via the $\kappa 3^{\prime}$ enhancer in B cells (Park and Atchison 1991). Presumably, this functional versatility results from the interaction of ubiquitous YY-1 with specific transcription factors at different promoters. The genetic analysis presented here suggests certain candidates for spatially localized factors with which Opa could cooperate.

In the even parasegment, our data support a combinatorial model wherein $\mathrm{Ftz}$ activates en expression and odd restricts this activation to the anterior-most Ftz-express- ing cells (Fig. 8; Manoukian and Krause 1992, 1993). An essential facet of this model is that Opa must repress odd transcription in a specific cell, the anterior-most Ftz-expressing cell, to allow induction of $e n$ by Ftz (Fig. 8). The Run pair-rule protein is a candidate for a cofactor with which Opa may cooperate to specifically repress odd. The Ftz protein itself peaks in concentration in the anterior cell of its expression domain. Run is also expressed in these anterior-most $\mathrm{Ftz}^{+}$cells (Kania et al. 1990). Perhaps an interaction between Opa and Run masks the Opa activator domain, and subsequent binding of this complex to the odd promoter represses odd transcription in these cells.

Opa acts as a positive regulator in other cells. Perhaps

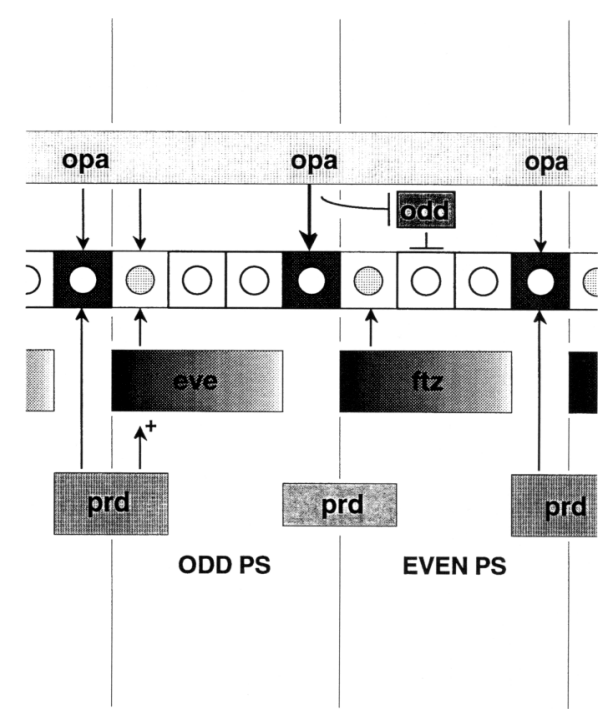

Figure 8. Pair-rule genetic interactions regulating en and $w g$ at cellular blastoderm. Two complete parasegments are shown, with en-expressing cells (filled nuclei) at the anterior and wgexpressing cells (filled cytoplasm) at the posterior of each parasegment. eve is expressed in a graded manner across the odd parasegments as it retracts to the anterior-most cell of the parasegments. The anterior-most eve-expressing cell overlaps with one domain of prd expression, and eve and prd together appear to activate en expression (filled nuclei) in these parasegments (Morrissey et al. 1991). This prd domain straddles the even/odd parasegment border and activates $w g$ (filled cytoplasm) in the even parasegments (Ingham et al. 1988). opa assists in wg activation here, too (thin arrow), because these wg stripes are weaker than normal in opa mutants. In the even parasegments, $f t z$ is expressed in a gradient similar to eve. $f t z$ eventually retracts to the anterior-most cell of the parasegments. Initially, odd is expressed in a broad domain coinciding with broad $f t z$ stripes. opa represses odd in the anterior cells of the $f t z$ domain (1). odd represses $f t z$-dependent activation of en $(\perp)$, allowing activation of $e n$ in only this anterior-most cell (Manoukian and Krause 1993|. opa may also act directly to activate en in this cell. opa activates $w g$ in the odd parasegments (thick arrow) (Ingham et al., 1988). The prd stripes that straddle the odd/even parasegments boundary express prd at a lower level than the other stripes. This prd domain probably helps opa to activate $w g$, because in prd mutants these wg stripes are weaker than wild-type stripes (J.R. Mullen, unpubl.). 
in these cases, interactions with specific spatially restricted factors mask the repressor domain within Opa, allowing it to assist in transcriptional activation of target genes. Activation of en expression in the odd parasegment was thought to occur via a combination of Eve and Prd [Fig. 8; (DiNardo and O'Farrell 1987; Morrissey et al. 1991)]. Yet, eve expression is unaffected in opa mutants, and the changes in prd expression cannot account for the delay seen in en activation (Frasch and Levine 1987; Baumgartner and Noll 1990). Perhaps in these parasegments, Opa interacts with Prd and/or Eve to form a complex that stimulates en transcription.

\section{Opa sets the level, but not the position, of $\mathrm{wg}$ expression}

$f t z$ and eve have been genetically defined as negative regulators of wg expression, whereas prd and opa have been defined as activators (Ingham et al. 1988). It was hypothesized that as $f t z$ stripes narrowed, repression would be relieved at $w g$, allowing activation by prd in even parasegments (Fig. 8). A similar narrowing of eve stripes in the odd parasegments was hypothesized to allow activation of $w g$ by opa (Fig. 8). Because the repressors $f t z$ and $e v e$ eventually disappear, some mechanism must restrict $w g$ activation to narrow stripes. In the even parasegments this role was ascribed to prd, because its expression domain is restricted (Fig. 8). In the odd parasegments earlier models supposed a similar restriction in the domain of expression or function of opa. We have confirmed that opa function is essential for wg activation in the odd parasegments (Ingham et al. 1988) and have shown that opa is important for the timely activation of wg expression in the other parasegments. Thus, opa may directly activate $w g$ in the odd parasegments and assist in the prd-dependent activation of $w g$ in the even parasegments (Fig. 8); however, because opa is expressed throughout all segment primordia and appears to act in all cells in which it is expressed, opa alone cannot determine the restricted position of $w g$ expression in odd parasegments. The spatial information that restricts $w g$ expression in the odd parasegments must reside with other pair-rule, or as yet uncharacterized, proteins.

\section{Early global defects are partially resolved through cellular interactions}

Given the global effects on gene expression at cellular blastoderm in the absence of opa, one might expect defects more severe than pair-rule deletions in body pattern. The final pattern in opa mutants, however, is not surprising if one considers the cell signaling circuits that function during postblastoderm development. In wildtype embryos, after wg and en expression are initiated in adjacent cells, wg input to the neighboring cells maintains the expression of $e n$ in those cells (DiNardo et al. 1988; Martinez-Arias et al. 1988). wg even appears to have the capacity to boost low levels of en expression (Bejsovec and Martinez-Arias 1991). Reciprocally, wg expression is reinforced by a signal from adjoining en-ex- pressing cells (Martinez-Arias et al. 1988). As a consequence of these interactions, the parasegment boundaries are stabilized and normal body pattern is generated. In opa mutants, although en expression eventually initiates in the even parasegments, the lack of $w g$ expression in the anteriorly adjacent cell (in the odd parasegments) leads to premature decay of these en stripes. The boundaries between these parasegments are destabilized, leading to fusion of alternate parasegments and deletion of the odd denticle belts. At the other parasegment boundaries, $w g$ expression is initiated, albeit at reduced levels, and en expression is severely delayed. The mutual positive feedback between adjacent $w g$ - and en-expressing cells, however, stabilizes these parasegment boundaries, such that the final body pattern exhibits only pairrule defects. Thus, the global defects observed in opa mutants at cellular blastoderm are partially compensated for later by the regulative properties of the $e$ and $w g$ cells flanking these parasegment boundaries.

Other proteins may be found that, like Opa, play a spatially restricted role but are not spatially restricted in their expression. Such proteins need not be zygotically expressed, but could be deposited maternally during oogenesis, because their restricted activity does not hinge on limited expression. The homeotic gene extradenticle is one such gene that is uniformly expressed in the embryo during the period when it modulates Ultrabithorax (Ubx) activity (Rauskolb 1993). At least one other maternal effect lethal mutation that leads to patterned defects within the embryo has been identified (Perrimon and Mahowald 1986), and genetic screens are being conducted for other maternal factors. Current models for Drosophila segmentation are based on combinatorial interactions among patterned transcriptional regulators. These models will have to accommodate interactions with ubiquitous factors as more of them are identified.

\section{Materials and methods}

Fly stocks

Flies were maintained on standard cornmeal/molasses/agar, at $25^{\circ} \mathrm{C}$ or $18^{\circ} \mathrm{C}$. The EMS-derived opa alleles were obtained from the Tübingen stock center. Deficiencies in Figure 1 were obtained from Steve Wasserman (Letsou et al. 1991), except for $D f$ $Z$-1, which was generated as follows: rosy (ry) males, homozygous for the $\mathrm{P}\left(t a 3 ; r \mathrm{y}^{+}\right)$transgene, were irradiated with $4 \mathrm{krads}$ and mated to MKRS ry/TM3 Sb, ry virgin females. The flies were allowed to lay for 4 days, and the $F_{1}$ flies were screened for ry eye color. Of 9971 flies, 7 were identified as ry, 4 of which were recoverable. One of these, $D f Z-1$, was cytologically visible $\left(82 \mathrm{~A} ; 82 \mathrm{E}_{3-4}\right)$ and failed to complement the opa EMS alleles. Balancer chromosomes used were TM3 Sb $\mathrm{P}(p t h b-1 a c Z)$ (Driever et al. 1989), provided by M. Weir, and TM6B $\mathrm{Tb} \mathrm{P}\left(\mathrm{y}^{+}\right)$, provided by Ed Grell (University of California, San Francisco).

\section{Chromosome walk}

The EMBL3 genomic library (Frischauf et al. 1983) used was constructed and provided by John Tamkun (University of Arizona, Tucson). The walk was initiated using a genomic phage clone (from Bill Kalionis and Rob Saint, University of Adelaide, 
Australia) that mapped to the centromere proximal edge of $D f$ $3 R(6-7)$. Whole phage DNA was isolated individually from each phage mapping under $D f 3 R(6-7)$ and digested with Sau3A. One hundred nanograms from each phage preparation was labeled with digoxigenin (Boehringer Mannheim Biochemical) in a reaction volume of $20 \mu \mathrm{l}$ according to manufacturer's instructions, except the reaction took place in a silated Eppendorf tube for $10 \mathrm{hr}$ at room temperature. The reactions were stopped by heating to $65^{\circ} \mathrm{C}$ for $10 \mathrm{~min}$, and $20 \mu \mathrm{g}$ of glycogen, $1 / 10$ volume of $3 \mathrm{~m}$ sodium acetate, and 2 volumes of ethanol were added and the reaction products precipitated on dry ice for $30 \mathrm{~min}$. The reaction products were pelleted for $10 \mathrm{~min}$ in an Eppendorf centrifuge, aspirated, and washed with $1 \mathrm{ml}$ of $70 \%$ ethanol, dried, and resuspended in $50 \mu \mathrm{l}$ of hybridization buffer. Of this buffer, 4,8 , or $12 \mu \mathrm{l}$ was used to hybridize fixed preparations of embryos (see below). Similarly treated DNAs from a phage containing the first exon of the en gene and our starting phage, which mapped outside of the opa deficiency, were used as positive and negative controls, respectively. Thirty-eight cDNAs were obtained by screening $2 \times 10^{5}$ colonies of a 0 - to 4 -hr cDNA plasmid library obtained from Nick Brown (Brown and Kafatos 1988). Four clones were analyzed in detail (see Sequence analysis below).

\section{Primer extension}

The primer Pext (TTTCGCTCTTAGATATTTCGCATGCGACTT), extending from +148 to +119 on the noncoding strand of opaC, was used for primer extension experiments. Primer extension was performed according to Ausubel et al. (1987). Prior to gel electrophoresis the reaction product was boiled for $3 \mathrm{~min}$ in sequencing buffer $180 \%$ formamide, $0.5 \times \mathrm{TBE}, 0.1 \%$ xylene cyanol, and bromphenol blue) and placed on ice. The sample was run on a $6 \%$ polyacrylamide sequencing gel with sequencing reactions from two different primers as size standards.

\section{Construction of transgenic HSopa line}

The opa cDNAs were originally in pNB40 (Brown and Kafatos 1988). A 2.8-kb HindIII fragment from opaC was cloned into pKS + (Stratagene), yielding pKS-opadIII. The 5' HindIII site comes from pNB40, whereas the $3^{\prime}$ HindIII site resides at position 2795 of opaC. pKS-opadIII was cut partially with HincII and completely with $\mathrm{XbaI}$. The resulting fragment was cloned into HpaI/XbaI-cut pCaSpeR-HS (Mohler et al. 1989), to yield pCaHSopa. Transgenic lines were constructed in the standard manner, using "wings-clipped" as a helper at $150 \mu \mathrm{g} / \mathrm{ml}$ (Karess and Rubin 1984). A transgenic line that mapped to chromosome II was used to establish the experimental stock: yw; HSopa/ HSopa; $\mathrm{opa}^{5 \mathrm{H}} / \mathrm{TM}_{\mathrm{B}} \mathrm{B}\left(\mathrm{y}^{+}\right)$. From the crosses carried out to establish this stock, an isolate of $o p a^{5 H} / \mathrm{TM} 6 \mathrm{~B} \mathrm{P}\left(y^{+}\right)$in the same genetic background as the experimental stock, but without the HSopa transgene, was used as a negative control.

\section{Rescue experiments}

Injection of in vitro synthesized mRNA A $2.8-\mathrm{kb}$ EcoRI fragment from opaC was subcloned into $\mathrm{pKS}+$ (Stratagene), yielding pKS-opaRI. Both EcoRI sites were derived from the NB40 vector. This EcoRI fragment included the SP6 RNA polymerase promoter from NB40, allowing the in vitro transcription of opa mRNA. Ten micrograms of pKS-opaRI was linearized with $X b a I$ and incubated at $37^{\circ} \mathrm{C}$ with $1 \mathrm{~mm}$ each rATP, rCTP, rUTP, and GpppGTP, $0.1 \mathrm{~mm}$ rGTP, $1.6 \mathrm{U} / \mu \mathrm{l}$ RNasin (Promega), and 40 units of SP6 RNA polymerase in a total volume of $100 \mu$ in the appropriate buffer (Promega). After $1.5 \mathrm{hr}, 0.05 \mathrm{~mm}$ rGTP and 40 units of SP6 RNA polymerase were added and the incubation was continued. One hour later, 60 units of RNase-free DNase I (Boehringer Mannheim Biochemical) was added, and the mixture was incubated for $20 \mathrm{~min}$ at $37^{\circ} \mathrm{C}$. The mixture was diluted with an equal volume of water, phenol/chloroform/ isoamyl alcohol extracted, and ethanol precipitated twice to remove free nucleotides. The pellet was resuspended in $20 \mu \mathrm{lof}$ water and injected at $\sim 1 \mathrm{mg} / \mathrm{ml}$ into embryos from wy; opa ${ }^{5 H} /$ TM6B P $\left(\mathrm{y}^{+}\right)$parents. Embryos were collected for $30 \mathrm{~min}$, and aged for $60 \mathrm{~min}$ at $25^{\circ} \mathrm{C}$, dechorionated with bleach, and injected at $\sim 50 \%$ egg length under oil at $18^{\circ} \mathrm{C}$ (at $\sim 2-2.5 \mathrm{hr}$ after egg laying). Injected embryos were placed at $18^{\circ} \mathrm{C}$ for $\sim 40 \mathrm{hr}$, fixed overnight in $5 \%$ formaldehyde/PBTw, and devitellinized manually. Embryos were rinsed, rehydrated in PBTw for $1 \mathrm{hr}$ at $37^{\circ} \mathrm{C}$, mounted in Hoyer's/lactic acid/water $(1: 1: 1)$, and cleared overnight at $65^{\circ} \mathrm{C}$.

Heat shock protocol For cuticle rescue, embryos from yw; HSopa/HSopa; opa ${ }^{5 H} / \mathrm{TM}_{\mathrm{B}} \mathrm{P}\left(\mathrm{y}^{+}\right)$parents, or from control flies without the HSopa construct were collected on grape agar plates and aged at $25^{\circ} \mathrm{C}$. Chorions were cleared with $27 \mathrm{~S}$ halocarbon oil, and cellularizing embryos, representing stage 5 of development ( $~ 50 \mathrm{~min}$; Campos-Ortega and Hartenstein 1985), were transferred to a fresh plate. The plate was floated in a $37^{\circ} \mathrm{C}$ water bath for $20 \mathrm{~min}$, and returned to $25^{\circ} \mathrm{C}$. After $\sim 30 \mathrm{hr}$, hatched and unhatched embryos were processed to observe cuticle pattern (Meer 1977). Under bright-field optics yw; opa $a^{5 H} / \mathrm{opa}^{5 H} \mathrm{em}-$ bryos can be identified unambiguously because their ventral denticles lack pigment, whereas their wild-type siblings carry the $\mathrm{P}\left(\mathrm{y}^{+}\right)$transgene on the TM6B balancer chromosome. For rescue of $e n$ and $w g$ expression, embryos from HSopa/HSopa; $o p a^{7 N} / \mathrm{TM} 3 \mathrm{P}(\mathrm{pthb}-\mathrm{lacZ})$ parents, or from control flies lacking the HSopa transgene, were collected and heat-shocked as above, returned to $25^{\circ} \mathrm{C}$ for $1 \mathrm{hr}$, fixed, and processed for in situ hybridization or immunohistochemistry as detailed below. The absence of $l a c Z$ expression identified the opa homozygous mutant embryos.

\section{Sequence analysis}

Four different cDNAs were isolated, opaA, opaB, opaC, and $o p a D$. Of these, opaC represented a full-length clone, with $o p a A, o p a B$, and opaD being $5^{\prime}$ deletions thereof. Nested deletions of the opaC subclone in both orientations in $\mathrm{pKS}+$ were made using the Erase-A-Base kit (Promega) according to manufacturer's instructions. Sequencing was performed using the double-stranded chain termination method (Sanger et al. 1977), the Sequenase 2.0 sequencing kit (U.S. Biochemical) and $\left[{ }^{35}\right.$ S $]$ dATP. Terminal deoxynucleotide transferase and deazasubstituted nucleotides (U.S. Biochemical) were used to resolve compressions. Recently, Cimbora and Sakonju have independently cloned the opa gene (D. Cimbora and S. Sakonju, in prep.). During preparation of this manuscript, we exchanged sequence information and Dan Cimbora identified an extra nucleotide at position 1781 relative to our sequence. Sequencing and restriction analysis confirmed that this nucleotide was present in opaA, opaB, and opaD, but not in opaC. Therefore, opaC generates a carboxy-terminal truncated protein of 509 amino acids, which nevertheless rescues opa mutant embryos. The sequence reported here and to GenBank is the corrected one. Sequences were assembled using the PC/GENE ASSEMGEL and SEQIN programs. The PC/GENE TRANSL program was used to conceptually translate the cDNA sequence. The PIR, SwissProt, and GenPept data bases were searched with the conceptual opa translation using the BLAST algorithm (Altschul et al. 1990|. Alignment comparison of the zinc finger do- 
mains from the Opa, GLI, $\mathrm{Ci}^{\mathrm{D}}$, and Tra-1 proteins was performed using the PC/GENE CLUSTAL program.

\section{Exon mapping}

cDNA probes on Southern blots of phage clones 6,7 , and 8 were used to map exons to individual genomic restriction fragments. Restriction site comparisons between these fragments and the opaC cDNA further refined the location of individual exons within these fragments. The restriction fragments were subcloned into pKS + and used as templates for PCR and sequencing comparisons in parallel with similar reactions on the opaC cDNA to verify location of exons not confirmed by restriction analysis or Southern blotting. Exon 1 mapped to a genomic 6-kb BamHI fragment. The $5^{\prime}$ and $3^{\prime}$ end points of the exon within the fragment were determined by sequencing the $6-\mathrm{kb}$ BamHI template with primers from the cDNA sequence. Exon 1 is 1243 bp and is completely within the 6-kb BamHI genomic fragment. Exons 2 and 3 lay within a 4.5-kb BamHI-SalI genomic fragment. Bases 1414-2959 of the opaC cDNA constituted exon 3. All primers were obtained from Operon Technologies.

\section{$\operatorname{Poly}(A)^{+}$mRNA isolation}

Total RNA was isolated according to Dorsett et al. (1989). After resuspension of total mRNA in $0.4 \mathrm{M} \mathrm{NaCl}, 10 \mathrm{mM}$ Tris (pH 7.5), $5 \mathrm{mM}$ EDTA, and $0.5 \%$ SDS, the solution was passed over an oligo(dT)-cellulose column (Collaborative Research), which was then washed exhaustively with the same solution prepared without SDS. The poly $(\mathrm{A})^{+}$fraction was eluted with TE and stored at $-70^{\circ} \mathrm{C}$. Formaldehyde gels and Northern blotting procedures were as specified in Sambrook et al. (1989).

\section{Antibody production}

A BamHI fragment from opaC in NB40 was subcloned into BamHI-cut, phosphatased pAR3040, a T7 RNA polymerase expression vector (Rosenberg et al. 1987). The $3^{\prime}$ BamHI site is from NB40, whereas the $5^{\prime}$ BamHI site is at position 591 in opaC. The construct fuses the first 10 amino acids of $\mathrm{T} 7$ gene 10 with the carboxy-terminal 410 amino acids of opa. The construct was transfected into BL2l(DE3) cells and induced with $0.4 \mathrm{~mm}$ IPTG for $2 \mathrm{hr}$ at $37^{\circ} \mathrm{C}$. Cells were pelleted, washed with lysis buffer (LB) (50 mM Tris at pH 8.0, $1 \mathrm{~mm} \mathrm{DTT,} 1 \mathrm{mM}$ PMSF, $0.01 \% \mathrm{NP}-40)$, resuspended in LB plus lysozyme $(1 \mathrm{mg} / \mathrm{ml})$, and incubated for $30 \mathrm{~min}$ on ice. The mixture was frozen and thawed for three cycles, and sonicated three times for $10 \mathrm{sec}$. Inclusion bodies were pelleted at $10,000 \mathrm{rpm}$ in a JS-13.1 rotor for $20 \mathrm{~min}$ at $4^{\circ} \mathrm{C}$. Inclusion bodies were washed three times in LB plus $0.1 \% \mathrm{NP}-40$ (washing means resuspension, sonication, and pelleting), once in LB, and once in PBS. Inclusion bodies were then resuspended in PBS at $4 \mathrm{mg} / \mathrm{ml}$ and dispersed through progressively finer gauge needles. One milliliter of inclusion bodies was mixed 1:1 with Freund's complete adjuvant and injected into rabbits. Boosts were identical except they were mixed $1: 1$ with incomplete adjuvant.

\section{In situ labeling for RNA and protein}

In situ hybridization and protein staining of embryos was performed as in Dougan and DiNardo (1992). The anti-Ftz antibody was a gift from $H$. Krause (Krause et al. 1988) and was used at a dilution of 1:500 (Kellerman et al. 1990). The odd probe was a gift from D. Coulter (Coulter et al. 1990).

\section{Acknowledgments}

We are grateful to the laboratory, especially to Scott Dougan and Monica Boyle, along with an anonymous reviewer for critical readings of this paper, and acknowledge the stimulating environment provided by Desplan-DiNardo laboratory interactions. We are deeply indebted to Dan Cimbora and Shigeru Sakonju for providing information prior to publication. We thank Eric Wieschaus, the Tübingen stock Center, Doug Coulter, John Postlethwait, Nick Brown, Ed Grell, Michael Weir, Bill Kalionis, Rob Saint, and Henry Krause for providing various fly stocks and reagents; Simon Kidd for the Northern blot; Gregg Thomas and Jim Cleaver of the Laboratory of Radiation Biology at the University of California at San Francisco for use of the $\mathrm{X}$-ray source; Kevin Moses for advice about the mutagenesis, and Louise O'Keefe. We are especially grateful to Steve Wasserman and members of his laboratory for deficiencies, $\gamma$-ray mutants, clones, and free exchange of ideas and strategies. This work began while S.D. was a postdoctoral fellow in Pat O'Farrell's laboratory at the University of California at San Francisco, and he is grateful for Pat's support, advice, and continued encouragement. M.J.B. was supported by the Lucille P. Markey Charitable Trust. J.R.M. was partially supported by the National Institutes of Health (GM-13838). S.D. is a Lucille P. Markey Scholar, and this work was supported by the Markey Charitable Trust, and the NIH (GM-45747).

The publication costs of this article were defrayed in part by payment of page charges. This article must therefore be hereby marked "advertisement" in accordance with 18 USC section 1734 solely to indicate this fact.

\section{Note added in proof}

The sequence data described in this paper have been submitted to the GenBank data library under accession number U04435.

\section{References}

Altschul, S.F., W. Gish, W. Miller, E.W. Myers, and D.J. Lipman. 1990. Basic local alignment search tool. I. Mol. Biol. 215: $403-410$.

Ausubel, F.M., R. Brent, R.E. Kingston, D.D. Moore, J.G. Seidman, J.A. Smith, and K. Struhl. 1987. Current protocols in molecular biology. Wiley Interscience, New York.

Babu, P. 1977. Early developmental subdivisions of the wing disc in Drosophila. Mol. Gen. Genet. 151: 289-294.

Baker, N.E. 1987. Molecular cloning of sequences from wingless a segment polarity gene in Drosophila: The spatial distribution of a transcript in embryos. EMBO J. 6: 1765-1773.

Baumgartner, S. and M. Noll. 1990. Network of interactions among pair-rule genes regulating paired expression during primordial segmentation of Drosophila. Mech. Dev. 1: 1-18.

Bejsovec, A. and A. Martinez-Arias. 1991. Roles of wingless in patterning the larval epidermis of Drosophila. Development 113: $471-485$.

Brown, N.H. and F.C. Kafatos. 1988. Functional cDNA libraries from Drosophila embryos. J. Mol. Biol. 203: 425-437.

Campos-Ortega, J.A. and V. Hartenstein. 1985. The embryonic development of Drosophila melanogaster. Springer-Verlag, New York.

Carroll, S.B. and M.P. Scott. 1985. Localization of the fushi tarazu protein during Drosophila embryogenesis. Cell 43: $47-57$.

-1986. Zygotically active genes that affect the spatial expression of the fushi tarazu segmentation gene during early Drosophila embryogenesis. Cell 45: 113-126.

Carroll, S.B., A. Laughon, and B.S. Thalley. 1988. Expression 
function and regulation of the hairy segmentation protein in the Drosophila embryo. Genes \& Dev. 2: 883-890.

Carroll, S.B., S. DiNardo, P.H. O'Farrell, R.A.H. White, and M.P. Scott. 1988b. Temporal and spatial relationships between segmentation and homeotic gene expression in Drosophila embryos: Distributions of the fushi tarazu, engrailed, Sex combs reduced, Antennapedia, and Ultrabithorax proteins. Genes \& Dev. 2: 350-360.

Cavener, D.R. 1987. Comparison of the consensus sequence flanking translational start sites in Drosophila and vertebrates. Nucleic Acids Res. 15: 1353-1361.

Coulter, D.E., E.A. Swaykus, M.A. Beran-Koehn, D. Goldberg, E. Wieschaus, and P. Schedl. 1990. Molecular analysis of odd-skipped a zinc finger encoding segmentation gene with a novel pair-rule expression pattern. EMBO I. 8: 3795-3804.

Courey, A.J. and R. Tjian. 1988. Analysis of $\mathrm{Spl}$ in vivo reveals multiple transcriptional domains including a novel glutamine-rich activation motif. Cell 55: 887-898.

Courey, A.J., D.A. Holtzman, S.P. Jackson, and R. Tjian. 1989. Synergistic activation by the glutamine-rich domains of human transcription factor Spl. Cell 59: 827-836.

DiNardo, S. and P.H. O'Farrell. 1987. Establishment and refinement of segmental pattern in the Drosophila embryo: Spatial control of engrailed expression by pair rule genes. Genes \& Dev. 1: 1212-1225.

DiNardo, S., E. Sher, J. Heemskerk-Jongens, J.A. Kassis, and P.H. O'Farrell. 1988. Two-tiered regulation of spatially patterned engrailed gene expression during Drosophila embryogenesis. Nature 332: 604-609.

Dorsett, D., G.A. Viglianti, B.J. Rutledge, and M. Meselson. 1989. Alteration of $h s p 82$ gene expression by the gypsy transposon and suppressor genes in Drosophila melanogaster. Genes \& Dev. 3: 454-468.

Dougan, S.T. and S. DiNardo. 1992. wingless generates cell type diversity among engrailed expressing cells. Nature 360: 347-350.

Driever, W., G. Thoma, and C. Nüsslein-Volhard. 1989. Determination of spatial domains of zygotic gene expression in the Drosophila embryo by the affinity of binding sites for the bicoid morphogen. Nature 340: 363-367.

Eaton, S. and T.B. Kornberg. 1990. Repression of $c i^{D}$ in posterior compartments of Drosophila by engrailed. Genes \& Dev. 4: 1068-1077.

Figdor, M.C. and C.D. Stern. 1993. Segmental organization of embryonic diencephalon. Nature 363: 630-634.

Frasch, M. and M. Levine. 1987. Complementary patterns of even-skipped and fushi tarazu expression involve their differential regulation by a common set of segmentation genes in Drosophila. Genes \& Dev. 1: 981-995.

Frasch, M., T. Hoey, C. Rushlow, H. Doyle, and M. Levine. 1987. Characterization and localization of the even-skipped protein of Drosophila. EMBO J. 6: 749-759.

Frischauf, A.-M., H. Lehrach, A. Poustka, and N. Murray, 1983. Lambda replacement vectors carrying polylinker sequences. I. Mol. Biol. 170: 827-842.

Garcia-Bellido, A., P. Ripoll, and A.G. Morata. 1973. Developmental compartmentalization of the wing disc of Drosophila. Nature New Biol. 245: 251-253.

. 1976. Developmental compartmentalization of the dorsal mesothoracic disc of Drosophila. Dev. Biol. 48: 132-147.

Gergen, J.P. and A.B.A. Butler. 1988. Isolation of the Drosophila segmentation gene runt and analysis of its expression during embryogenesis. Genes \& Dev. 2: 1179-1193.

Goto, T., P. Macdonald, and A.T. Maniatis. 1989. Early and late periodic patterns of even-skipped expression are controlled by distinct regulatory elements that respond to different spa- tial cues. Cell 57: 413-422.

Grossniklaus, U., R.H. Pearson, and W.J. Gehring. 1992. The Drosophila sloppy-paired locus encodes two proteins involved in segmentation that show homology to mammalian transcription factors. Genes \& Dev. 6: 1030-1051.

Hafen, E., A. Kuroiwa, and A.W.J. Gehring. 1984. Spatial distribution of transcripts from the segmentation gene fushi tarazu during Drosophila embryonic development. Cell 37: 833-841.

Howard, K. and A.P. Ingham. 1986. Regulatory interactions between the segmentation genes fushi tarazu, hairy and engrailed in the Drosophila blastoderm. Cell 44: 949-957.

Ingham, P.W. 1988. The molecular genetics of embryonic pattern formation in Drosophila. Nature 335: 25-34.

- 1991. Segment polarity genes and cell patterning within the Drosophila body segment. Curr. Opin. Genet. Dev. 1: 261-267.

Ingham, P.W. and A.A. Martinez-Arias. 1986. The correct activation of Antennapedia and bithorax complex genes requires the fushi tarazu gene. Nature 324: 592-597.

Ingham, P.W., K.R. Howard, and D. Ish-Horowicz. 1985. Transcription pattern of the Drosophila segmentation gene hairy. Nature 318: 439-445.

Ingham, P.W., N.E. Baker, and A. Martinez-Arias. 1988. Regulation of segment polarity genes in the Drosophila blastoderm by fushi tarazu and even-skipped. Nature 331: 73-75.

Jürgens, G., E. Wieschaus, C. Nüsslein-Volhard, and A.M. Kluding. 1984. Mutations affecting the pattern of the larval cuticle in Drosophila melanogaster. II. Zygotic loci on the third chromosome. Wilhelm Roux's Arch. Dev. Biol. 193: 283295.

Kakkis, E., K.J. Riggs, W. Gillespie, and K. Calame. 1989. A transcriptional repressor of $c$-myc. Nature 339: 718-721.

Kania, M.A., A.S. Bonner, J.B. Duffy, and A.J.P. Gergen, 1990. The Drosophila segmentation gene runt encodes a novel nuclear regulatory protein that is also expressed in the developing nervous system. Genes \& Dev. 4: 1701-1713.

Karess, R.E. and G.M. Rubin. 1984. Analysis of P transposable element functions in Drosophila. Cell 38: 135-146.

Kellerman, K.A., D.M. Mattson, and A.I. Duncan. 1990. Mutations affecting the stability of the fushi tarazu protein of Drosophila. Genes \& Dev. 4: 1936-1950.

Kilchherr, F., S. Baumgartern, D. Bopp, E. Frei, and A.M. Noll. 1986. Isolation of the paired gene of Drosophila and its spatial expression during early embryogenesis. Nature 321: 493-499.

Kornberg, T. 1981. Engrailed: A gene controlling compartment and segment formation in Drosophila. Proc. Natl. Acad. Sci. 78: 1095-1099.

Kornberg, T., I. Siden, P. O'Farrell, and A.M. Simon. 1985. The engrailed locus of Drosophila: In situ localization of transcripts reveals compartment-specific expression. Cell 40: 45-53.

Krause, H.M., R. Klemenz, and A.W.J. Gehring. 1988. Expression modification and localization of the Fushi Tarazu protein in Drosophila embryos. Genes \& Dev. 2: 1021-1036.

Lawrence, P.A., P. Johnston, P. Macdonald, and G. Struhl. 1987. Borders of parasegments in Drosophila embryos are delimited by the fushi tarazu and even-skipped genes. Nature 328: $440-442$.

Letsou, A., S. Alexander, K. Orth, and S.A. Wasserman. 1991. Genetic and molecular characterization of tube, a Drosophila gene maternally required for embryonic dorsoventral polarity. Proc. Natl. Acad. Sci. 88: 810-814.

Lewis, E. 1978. A gene complex controlling segmentation in Drosophila. Nature 276: 565-570. 
Licht, J.D., M.J. Grossel, J. Figge, and U.M. Hansen. 1990. Drosophila Kruppel protein is a transcriptional repressor. Nature 346: 76-79.

Lumsden, A. and R. Keynes. 1989. Segmental patterns of neuronal development in the chick hindbrain. Nature 337: 424428.

MacDonald, P.M., P. Ingham, and G. Struhl. 1986. Isolation, structure and expression of even-skipped: A second pair-rule gene of Drosophila containing a homeobox. Cell 47: 721734.

Manoukian, A.S. and H.M. Krause. 1992. Concentration-dependent activities of the even-skipped protein in Drosophila embryos. Genes \& Dev. 6: 1740-1751.

- 1993. Control of segmental asymmetry in Drosophila embryos. Development 118: 785-796.

Martinez-Arias, A. and P.A. Lawrence. 1985. Parasegments and compartments in the Drosophila embryo. Nature 313: 639642.

Martinez-Arias, A., N.E. Baker, and P.W. Ingham. 1988. Role of segment polarity genes in the definition and maintenance of cell states in the Drosophila embryo. Development 103: $157-170$.

Meer, S.V.D. 1977. Optical clean and permanent whole mount preparation for phase contrast microscopy of cuticular structures of insect larvae. Dros. Inf. Serv. 52: 160-161.

Mohler, J., E.D. Eldon, and V. Pirrotta. 1989. A novel spatial transcription pattern associated with the segmentation gene giant of Drosophila. EMBO I. 8: 1539-1548.

Morata, G. and P.A. Lawrence. 1975. Control of compartment development by the engrailed gene in Drosophila. Nature 255: 608-617.

Morrissey, D., D. Askew, L. Raj, and M. Weir. 1991. Functional dissection of the paired segmentation gene in Drosophila embryos. Genes \& Dev. 5: 1684-1696.

Noordermeer, J., P. Johnston, F. Rijsewik, R. Nusse, and P.A. Lawrence. 1992. The consequences of ubiquitous expression of the wingless gene in the Drosophila embryo. Development 116: 711-719.

Nüsslein-Volhard, C. and E. Wieschaus. 1980. Mutations affecting segment number and polarity in Drosophila. Nature 287: 795-801.

Nüsslein-Volhard, C., H. Kluding, G. Jürgens. 1985. Genes affecting the segmental subdivision of the Drosophila embryo. Cold Spring Harbor Symp. Quant. Biol. 50: 145-154.

Orenic, T.V., D.C. Slusarski, K.L. Kroll, and R.A. Holmgren. 1990. Cloning and characterization of the segment polarity gene cubitus interruptus Dominant of Drosophila. Genes \& Dev. 4: 1053-1067.

Pankratz, M.J., E. Seifert, N. Gerwin, B. Billi, U. Nauber, and H. Jäckle. 1990. Gradients of krüppel and knirps gene products direct pair-rule gene stripe patterning in the posterior region of the Drosophila embryo. Cell 61: 309-317.

Park, K. and M.L. Atchison. 1991. Isolation of a candidate repressor/activator, NF-E1 (yy-1, delta), that binds to the immunoglobulin kappa $3^{\prime}$ enhancer and the immunoglobulin heavy chain muEl site. Proc. Natl. Acad. Sci. 88: 9804 9808.

Perrimon, N. and A.P. Mahowald. 1986. 1(1)hopscotch, a larvalpupal zygotic lethal with a specific maternal effect on segmentation in Drosophila. Dev. Biol. 118: 28-41.

Poole, S.J. and T.B. Kornberg. 1988. Modifying expression of the engrailed gene of Drosophila melanogaster. Development (Suppl.) 104: 85-93.

Preiss, A., U.B. Rosenberg, A. Kienlin, E. Seifert, H. Jackle. 1985. Molecular genetics of Kruppel a gene required for segmentation of the Drosophila embryo. Nature 313: 27-32.
Rauskolb, C., M. Peifer, and E. Wieschaus. 1993. extradenticle, a regulator of homeotic gene activity, is a homolog of the homeobox-containing human proto-oncogene $p b \times 1$. Cell 74: 1101-1112.

Rosenberg, A.H., B.N. Lade, D. Chui, S. Lin, J.J. Dunn, and F.W. Studier. 1987. Vectors for selective expression of cloned DNAs by T7 RNA polymerase. Gene 56: 125-135.

Ruppert, J.M., B. Vogelstein, K. Arheden, and K.W. Kinzler. 1990. GLI3 encodes a 190-kilodalton protein with multiple regions of GLI similarity. Mol. Cell. Biol. 10: 5408-5415.

Sambrook, J., E.F. Fritsch, and T. Maniatis. 1989. Molecular cloning: A laboratory manual. Cold Spring Harbor Laboratory Press, Cold Spring Harbor, New York.

Sanger, F., S. Nicklen, and A.R. Coulson. 1977. DNA sequencing with chain-terminating inhibitors. Proc. Natl. Acad. Sci. 74: 5463-5467.

Sauer, F. and H. Jäckle. 1991. Concentration-dependent transcriptional activation or repression by Krüppel from a single binding site. Nature 353: 563-566.

Shi, Y., E. Seto, L.-S. Chang, and T. Shenk. 1991. Transcriptional repression by YY-1, a human GLI-Kruppel-related protein and relief of repression by adenovirus E1A protein. Cell 67: $377-388$

Stanojevic, D., T. Hoey, and M. Levine. 1989. Sequence-specific DNA-binding activities of the gap proteins encoded by hunchback and Kruppel in Drosophila. Nature 341: 331335 .

Zarkower, D. and J. Hodgkin. 1992. Molecular analysis of the $C$. elegans sex determining gene tra-1: A gene encoding two zinc finger proteins. Cell 70: 237-249.

Zuo, P., D. Stanojevic, J. Colgan, K. Han, M. Levine, and J.L. Manley. 1991. Activation and repression of transcription by the gap proteins hunchback and Krüppel in cultured Drosophila cells. Genes \& Dev. 5: 254-264. 


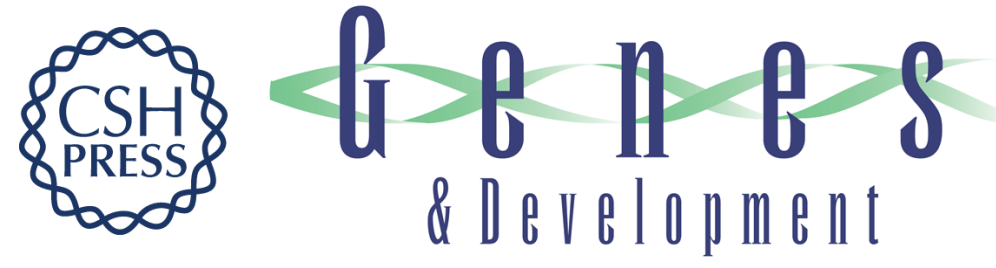

\section{odd-paired: a zinc finger pair-rule protein required for the timely activation of engrailed and wingless in Drosophila embryos.}

M J Benedyk, J R Mullen and S DiNardo

Genes Dev. 1994, 8:

Access the most recent version at doi:10.1101/gad.8.1.105

References This article cites 77 articles, 25 of which can be accessed free at: http://genesdev.cshlp.org/content/8/1/105.full.html\#ref-list-1

License

Email Alerting Service right corner of the article or click here.

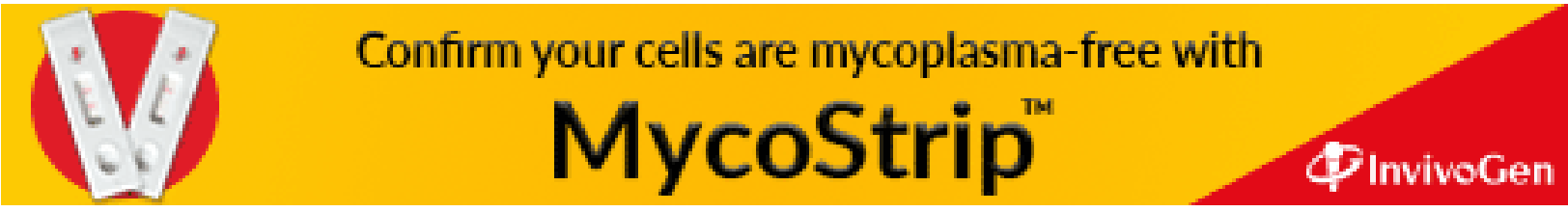

